\title{
An Analysis of Hydropower Project through Hall-Tri Dimension
}

\author{
* Dr. Tamoor Azam \\ ** Sadia Nelofer, PhD Scholar \\ *** Saqib Yaqoob Malik (Corresponding Author)
}

\begin{abstract}
Construction delays are a common phenomenon in the history of hydropower projects in the world generally and in Pakistan particularly. This research presents the case study of Diamar Basha Dam, one of the most delayed hydropower projects with a checkered history in Pakistan. Feasibility studies of Diamar Basha Dam have been carried out over the last 26 years and there seem to be no signs of its construction to date because of financial issues and territorial disputes with neighbors. It has also given a bird's eye view of unfathomable political conditions of the Kashmir dispute after the British colonization that gave rise to a new political identity to Gilgit Baltistan. The peaceful and fair solution to this political quagmire has been presented in this paper by employing Hall's TriDimension Model. If all three nuclear powers agreed on the given solution then this could ultimately lead to a healthier economic future of the entire region and could play a pivotal role in changing the face of South Asia because a country can make significant economic progress by harnessing adequately its water resources. The progressive economic future of the country largely hinges on hydropower plants because their advantages outweigh their disadvantages.
\end{abstract}

Keywords: China, Diamar Basha Dam, Gilgit Baltistan, Hydropower project, India, Kashmir Introduction Conflict, Pakistan...

Gilgit-Baltistan's history has distinctive phases, as pre-history up to the 7th century, medieval history till 1840, modern history from 1840 onwards, and post-independence history after 1947. When analyzed from historical outlook, the region has secluded from the rest of the world because of two reasons, first inaccessibility and second rough mountainous terrain when analyzed the history but it continued to be an epicenter of political and military rivalries amongst races of Central Asians, Chinese, Tibetans, Russians and British. The region has been at the crossroad of conquerors and defeater while the rock carvings in different areas in Gilgit-Baltistan shows a human existence since 2000 BC (Ian, 2015). The medieval period of Gilgit Baltistan doesn't trace its historical connection with Jammu and Kashmir but in the modern period, the region was a part of Jammu and Kashmir one of the princely states of the British Empire in the sub-continent from 1842 until 1947, ruled by a Jamwal Rajput Dogra Dynasty (Rai, 2004). In 1842 the \#Sikh dynasty of Lahore first-ever extended its province Jammu and Kashmir to western head-to-head hills by crossing the Indus river to Gilgit Baltistan invaded different areas of Gilgit Baltistan by taking advantage of feud amongst local rulers, invaded different parts of Gilgit Baltistan followed by British empire's cumulative interest in GilgitBaltistan to investigate and check Czar's Empire (Russian form of government, an absolute monarchy) and later Soviet Union's impending impact in the area, therefore the Fear of Russian aggression made them to found British Gilgit Agency in 1889, later the lease of Gilgit Baltistan in 1935 for 60 years from Maharaja of Kashmir by British marked the modern history of Gilgit Baltistan. At the end of the Second World War, the victorious countries were not in the state to rule over colonies because the people had been struggling to free themselves from foreign invasion for years. On the other hand, the spark of independence lit in Gilgit Baltistan on the based on "Two Nation Theory" and the second is that people of Gilgit Baltistan disliked being ruled by the Maharaja of

* Department of Management Sciences and Engineering, School of Management and Economics, Kunming University of Sciences and Technology, Yunnan, China Email: tamoorazam@ hotmail.com

** School of Research and Development, Department of Economics, Yunnan University, Kunming, China Email: mehkashamaher@gmail.com

*** College of Economics \& Management, Northeast Forestry University, Harbin 150040, China Email: malikhashir58@yahoo.com 
Kashmir state and the people in Gilgit Baltistan perceived themselves to be different from Kashmiris people ethnically (Bangeh, 2010). With the historical linkage of Gilgit Baltistan with Jammu and Kashmir, the predominant political force in Pakistan administered Kashmir "Muslim conference" ceded administration of the Gilgit Baltistan to the government of Pakistan without the consent of the people through the Karachi Agreement purportedly executed on April 1949 while this agreement is disliked and it has been rejected by the people of Gilgit Baltistan because they were not a party to it (Sahni, 2009). The administration of Gilgit Baltistan was transferred to Pakistan from Azad Kashmir because of two reasons: (1) Gilgit Baltistan was almost inaccessible to Azad Kashmir and (2) the governments of Pakistan and the government of Azad Kashmir knew that if the referendum takes place on Kashmir's final decision the people of the Gilgit Baltistan were in favor of joining Pakistan. After the independence Gilgit Baltistan was treated differently from the rest of Pakistan, there was no democratic set-up with a different administrative system. The post-independence status of Gilgit Baltistan is peculiar and distinctive, as it is the administrative and unconstitutional territory of Pakistan (Weightman, 2005) and part of the Kashmir conflict in tandem with an estimated population of 1,800,000 (Shahid, 2015) is spreading over an area of 72,400 Sq.km. In 2009 limited autonomy granted to Gilgit-Baltistan by the President of Pakistan through (Self-Governance and Empowerment) Order, the 'autonomy package' presented by the government for the people of Gilgit-Baltistan was a combination of bad and good news. The good news was that the "autonomy package" gave a first legislative assembly to Gilgit Baltistan and would ratify the name Gilgit Baltistan for what it was called the "Northern Areas of Pakistan" previously. The region would enjoy an autonomous status like other provinces there will be a chief minister and a governor with discretionary power. This reform had also established a council like a senate where there will be 15 members and it would be named "Gilgit-Baltistan Council" while the Prime Minister will be the Chairman of the council. The reform has also established the Public Service Commission, the Chief Election Commissioner, and the Auditor General. The bizarre news of the reform has upset the people that there will be only a province-like status, no institutional and constitutional link with the other four provinces of Pakistan (Order, 2009). Then in 2018, "Government of Gilgit Baltistan Order 2018", was introduced by the new government of Pakistan with an executive order calling it an updated and efficient version of the autonomy package "Government Order 2009". This new reform has altered the previous nomenclature of the Gilgit-Baltistan Legislative Assembly to Gilgit Baltistan Assembly. All powers entrusted to the Gilgit Baltistan Assembly exercised by the four provincial assemblies under Schedule IV of the Constitution of Pakistan. There are many flaws in "Government of Gilgit Baltistan Order 2018" but the biggest flaw is that this reform grant all the powers of the legislature, administration to the Prime Minister of Pakistan which makes the judicial system of the Gilgit Baltistan complaint to the Prime Minister of Pakistan. As the Prime Minister of Pakistan is the administrative head of the federation and holds his office under the Constitution, moreover the constitution doesn't empower him to make law while the parliament is the real law-making institution and President of Pakistan with limited powers to pass an ordinance. The "Government of Gilgit Baltistan Order 2018" has given ultra-constitutional powers to the Prime Minister as an "Emperor Powers" in the context of Gilgit Baltistan because he will rule without any powers conferred on him by the constitution. In this way, there will be a symbolic power of legislative assembly of Gilgit Baltistan and all legislative powers will be vested with the Prime Minister under Article 60(a) of the "proposed order" (Order, 2018). Despite all these people of Gilgit Baltistan still yearn for constitutional rights, access to the parliament, senate, and judicial system of Pakistan. They are expecting more autonomy in legislative powers and administrative matters but the hope of becoming a constitutional entity has never been dawned rather waning day by day till the present day.

\section{Political Quagmire}

"Although nuclear powers have never fought in any war the rift between India and Pakistan on Kashmir issue could give impetus to first nuclear war between them" (the US, President Richard Milhous Nixon, 1992). Kashmir (a former princely state of British India) is lying at the junction point of India, Afghanistan, Pakistan, and China in the Karakoram, Himalayan, and Hindukush Ranges. The territory, with an area of around 85,800 squares has been under the yoke of an unpleasant and unfathomable dispute, which has bedeviled the relationship among India, Pakistan, and China since the disintegration of the British Indian subcontinent in 1947. The entire territory of Jammu and Kashmir is divided among three nuclear superpowers. The northern and western parts are under the 
suzerainty of Pakistan and include two areas: Azad Kashmir and Gilgit Baltistan. The southern and south-eastern parts include the Indian state of Jammu and Kashmir. "Line of Control" of $778 \mathrm{~km}$ divides Pakistani and Indian administered territories. There is an undefined border in the Siachen glacier separating India and Pakistan, however, both India and Pakistan don't recognize it as an international boundary. China controls the eastern area of Ladakh, Aksai Chin (Aksai China was not the part of British India, Sushant, 2020) and the Trans-Karakoram Tract and parts of Demchok sector while "Line of actual control" of $489 \mathrm{~km}$ (189 sq. ml) separates India and China (P.Stobdan, 2020). During the partition time of Indian Jammu and Kashmir including Aksai Chin, Kashmir had 10 percent, Jammu 14.4 percent, and the frontier districts 75.6 percent (Musarat, 2015). The Political top brass from all these 3 Nuclear powers is involved in jibes for decades which gives no sign to its peaceful solution in terms of its fundamental right that is its constitutional status and the inception of any mega project which could be beneficial for its economic status. All these powers have their kind of perspective over this entire land.

\section{Indian Perspective}

India is rationally attached to the Kashmir issue. India regards Kashmir as a territorial issue and blames Pakistan's interference in the matters by supporting the local people (Mujahideen) she claims Jammu and Kashmir is an integral part of India. On the other hand, the Muslim majority status of the Jammu and Kashmir region is very significant to defend the Indian ideology of secularism and Kashmir is substantial for highlighting the image to the world that there is a Muslim majority population region in India. India did not comprise any other Muslim majority state so through it she demonstrates its secular credentials. Moreover, there is an intense fear of Indians that the loss of Kashmir will set an example for other territories in India to break apart, as there are many liberation movements are going on in India for years (Basrur, 2008). Kashmir is important for India for one more reason that it is the ancestral homeland to one of the founding fathers of India, the first Indian Prime Minister Jawaharlal Nehru. Being a leading figure on the Indian side, he used his power to retain Jammu and Kashmir within the Indian Union (Malik, 2002).

\section{Pakistani Perspective}

Pakistan is emotionally attached to Jammu and Kashmir. The importance of Kashmir for Pakistan is based on the two-nation theory because upon which the "All India Muslim League" (The political party of Muslims of India) demanded a separate country for Muslims (Mallah, 2007). Pakistan had been created as the putative homeland for the Muslims of the Sub-continent. This theory says that the Muslims and Hindus are two distinctive nations and under the domination of Hindu the Muslims of the subcontinent cannot follow their religious practices in full accordance with their beliefs that's why they cannot live together. Kashmir was the Muslim majority region with an 85\% Muslim population that has not given to Pakistan. Moreover, Kashmir abutted Pakistan that's why she had an irredentist claim on Kashmir. Kashmir is also meaningful for both India and Pakistan practically in the economic and strategic fields.

\section{Chinese Perspective}

The extension of the Tibetan Empire (618-842) stretches from the west, touches the Gansu province of current China to the east Xingjian, Kashmir, Ladakh, and Gilgit Baltistan regions. There is infect, substantial historical evidence of the presence of Buddhism in Gilgit Baltistan besides Ladakh. The rock carvings of Buddha, Manthal Buddha Rock in Baltistan, Kargha Buddha and Hanzal stupa (Stupa a dome-shaped structure erected as a Buddhist shrine) in Gilgit paves a clear and distinctive sign of Buddhist rules for such a long time (Sen 2015). Moreover, historical names of Gilgit Baltistan are present in the records of the Tang dynasty of China, Little Palola (Chinese: 小勃律) was the name given to Gilgit, while Great Palola (Chinese: 大勃律) was the name given to Baltistan in ancient times of pre-Islamic era (Karl, 1993). In this historical context Chinese also claim this entire region but in 1963, under the "Sino-Pakistani Frontier Agreement" Pakistan has given around 5,800 square kilometers of the land of Gilgit-Baltistan to China. China is occupying around 20,000 square kilometers including Shaksgam, Raskam, and Aghil valleys while this area has called the TransKarakoram Tract. Thus, China gained a permanent stake in this region (Ankit, 2014 and Senge, 2013) while in 1962 Sino-India war was fought for this region (Calvin, 1984) and once again both nucleararmed rivals India and China are on the brink of war after killing 20 Indian soldiers in a disputed border (Jeffer, 2020). 


\section{TERRITORIAL CLAIMS}
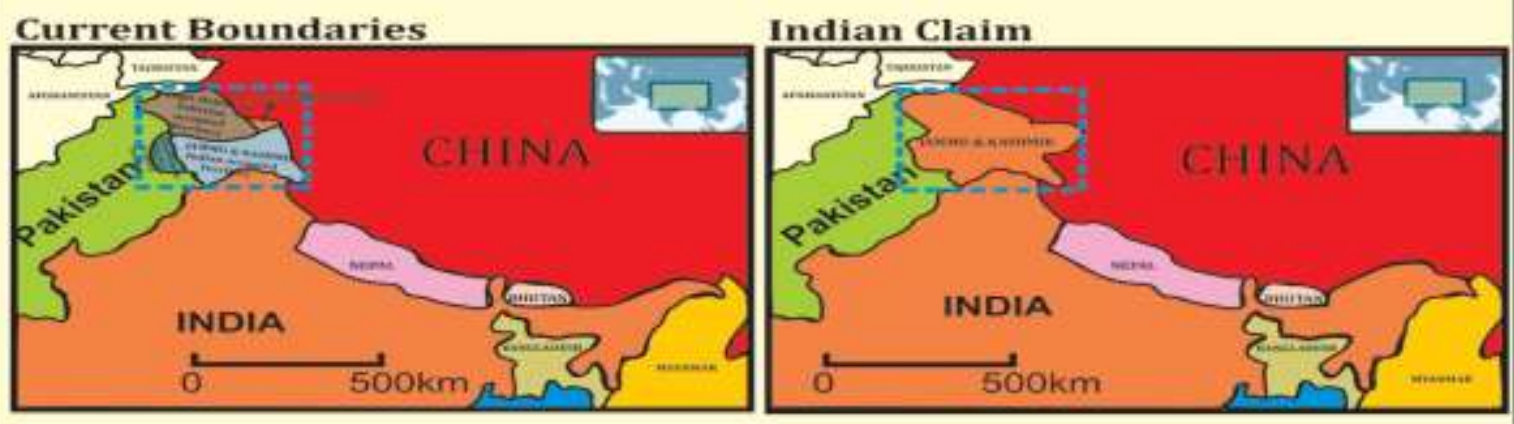

\section{Pakistani Claim}

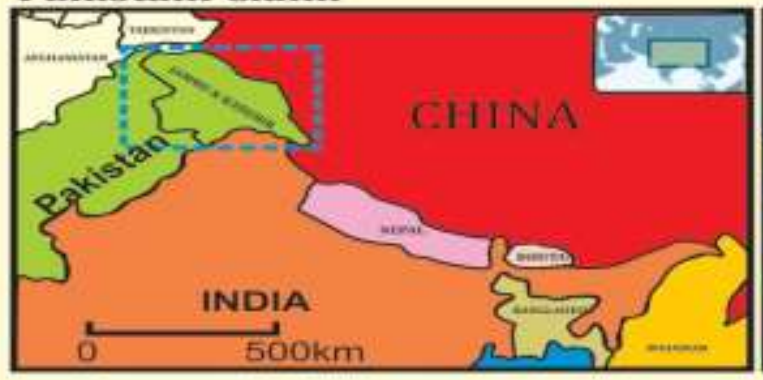

Chinese Claim

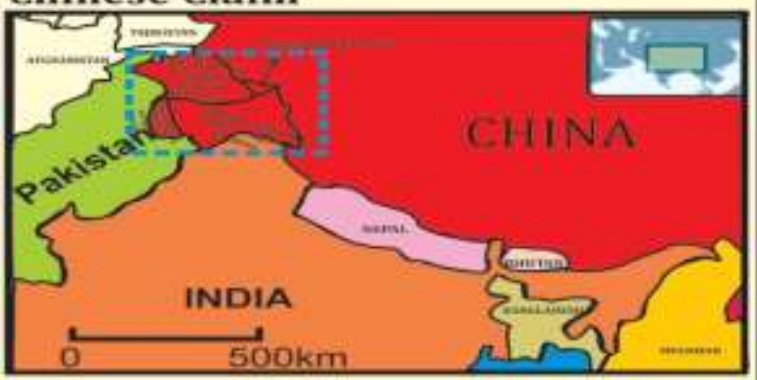

\section{Case study of Diamar Basha Dam}

\section{The Project}

Diamar Basha Dam is a concrete-filled gravity dam which is in the initial stages of construction for the last two decades, in 2006 it was announced officially for its construction but again it was delayed while the recent date to begin its construction is in May 2019 (Work, 2019). Upon completion, Diamar Basha Dam will produce 4,500 MW of electricity with the highest Roller Compacted Concrete dam in the world. The maximum height of Diamar Basha Dam will be $270 \mathrm{~m}$, with live storage of more than $6,400,000$ acre-feet $(7.89 \times 109 \mathrm{~m} 3)$ and it would impound a reservoir of about $7,500,000$ acre-feet $(9.25 \times 109 \mathrm{~m} 3)$. At the site, the mean annual discharge of Indus River is $50,000,000$ acre-feet $(6.2 \times 1010 \mathrm{~m} 3)$. Thus, the dam will impound $15 \%$ of the annual river flow. The dam will generate environmentally clean hydropower electricity generation that stores an extra $8,500,000$ acre-feet $(10.5 \mathrm{~km} 3)$ of water for the country which will be utilized for drinking and irrigation purposes and it would also control flood damage by the River Indus downstream during high floods (DBD, 2018).

\section{Project Location}

This region is shrouded by natural resources and dwellers living in a state of plight because of the Kashmir conflict. The location of the project on the Indus River which is about $315 \mathrm{~km}$ upstream of the earth-filled dam known as "Tarbela Dam" in Khyber Pakhtunkhwa, around $165 \mathrm{~km}$ downstream of the Gilgit (capital of Gilgit Baltistan) and $40 \mathrm{~km}$ downstream of Chilas (capital of Diamar District) and geographically it is located between longitude 73 to $75 \mathrm{E}$ and latitude 35 to $36 \mathrm{~N}$, around $110 \mathrm{~km} 2$ area would be covered by the dam project and $100 \mathrm{~km}$ extension upstream of the dam site up to Raikot Bridge on Karakoram Highway (KKH) in District Diamar. The entire area is mountainous that somewhere touches the fragments of Himalaya ranges. Natural Resources are conspicuously seen all around to the hilt with myriad kinds such as treasure of waters, forest, mines, minerals, flora, and fauna, etc. There are three world's famous gigantic series of mountain ranges the Karakoram, Himalaya, and Hindukush meet which are cladded with glaciers. Many renowned glaciers are found here like Siachen glacier, Biafo glacier, Baltoro glacier, and Batura glacier. Gilgit-Baltistan serves as a major water catchment (area of 72496 square kilometers) for the Indus River Basin (IRB) that comprises about $27 \%$ glaciers, the largest glacier in the world outside the polar region. Experts believe that the potential of hydropower on the main tributaries and Indus River is around 60,000 MW (Hussain, 2012). 


\section{Disputed Project Location}

Diamar Basha Dam has an unfortunate and tragic history because of its location in Gilgit Baltistan which is part of the Kashmir conflict. Project area lays in two most remote and negligent parts; the ownership of the tiny patch of land where the powerhouse will have to be constructed stretches over 8 $\mathrm{km}$ is disputed between the people of Diamar (Gilgit Baltistan a disputed land) and Kohistan (the most backward district of Khyber Pakhtunkhwa the province of Pakistan). The disputed region is historically administered under the control of the Gilgit Baltistan administration which is also a part of an unsettled territory without proper revenue records. Diamar Basha Dam has been designed in the way that the dam royalty will naturally to Khyber Pakhtunkhwa (KPK) as Article 161 (2) of the Pakistani Constitution (Constitution, 2012) stipulates that the royalty and the huge bulk of the net profits received from a hydroelectric station will move to the province where the hydropower station is situated. The Basha village (part of Khyber Pakhtunkhwa province) will include 1 percent of the reservoir, in this way, the income from the dam will go to KPK. Moreover, the Diamar Basha Dam project has encountered many impediments due to backing out of major sponsors from financing the project because of its controversial position in disputed territory, when the Asian Development Bank and World Bank appeared to have shown interest initially in the project and they are historically the major funders of many dams in Pakistan, has denied financing Diamar Basha Dam in 2012 because of its disputed location in a territory which has claimed by both Pakistan and India and the donors asked Pakistan to get Non-Objection Certificate (NOC) from India (Zaffer, 2012).

\section{Project Fund}

The then Finance Minister of Pakistan in 2013, claimed that he has convinced World Bank and Aga Khan Development Network to finance this project but all in vain (World, 2013), (Anam \& Shahbaz, 2013). Pakistan reached the "water stress line" in 1990 and traversed the "water scarcity line" in 2005. The fear was swirling that the country would touch the absolute water scarcity line in 2025 if the right decisions were not made at the right time. That time passed long ago. Water availability per capita in Pakistan has depleted to an alarming level. Past governments did little to deal with this massive crisis as it approached. At present, to deal with the crisis, the Chief Justice of Pakistan, Mian Saqib Nisar, initiated a dam fund for the construction of dams. He has recently ordered the setting up of a public fund for the Diamar Basha Dam project and personally initiating it with a (Pakistani) Rs 1 million donations by rejecting the offer of China to aid Diamar Basha Dam and requested China to eliminate the Diamar Basha Dam project from China Pakistan Economic Corridor (CPEC) the flagship project of the One Belt One Road initiative (Haseeb, 2018).

\section{Project Benefits}

- $\quad$ During the low flow period about 6,400,000 acre-feet $(7.89 \times 109 \mathrm{~m} 3)$, surface face water storage for irrigation supplies is available annually.

- Through an installed capacity of $4500 \mathrm{MW}$, a renewable source of clean and cheap energy will be harnessed.

- $\quad$ Dependence on thermal power will be reduced, thus saving foreign exchange

- Myriad opportunities for employment, especially for the locals, during the construction \& operating phase.

- Huge infrastructure will lead to rising living standards and socio-economic uplift of the people.

\section{Brief Description of Project Studies}

Formal techno-economic evaluation/feasibility studies have been carried out over the last 26 years but works are underway intermittently (DBD, 2004).

1. In 1984, Montreal Engineering Company (MONENCO) of Canada has first ever carried out its feasibility report.

2. in 2002, (a joint venture NEAC) International \& National engineering firms with M/s. NESPAK submitted feasibility report.

3. In 2008, a joint venture of international \& national consulting firms, M/s. Lahmeyar International Germany has submitted the feasibility report.

\section{Reasons behind the delay of Dam}

- $\quad$ Resettlement of People

- Land Compensation

- $\quad$ Disputed territory and boundary 
- $\quad$ Ecological Impact

- Threatens Cultural Heritage

\section{Construction Plan}

1. Phase 1

2. Phase 2

3. Phase 3

\section{Period of Implementation \\ 2001 to 2006 \\ 2006 to 2011 \\ 2011 to 2025 and onward}

\section{Main Dam}

- $\quad$ Maximum height: 272 meters

- $\quad$ Type: Roller Compacted Concrete (RCC)

- $\quad$ Reservoir Level: $1160 \mathrm{~m}$

- $\quad$ Total Installed Capacity: 4,500 MW

- $\quad$ Estimated Cost: US \$14 Billion (2013 Estimate)

\section{Methodology}

\section{Hall's Tri-Dimension Model}

This study quotes the holistic framework of Hall's three-dimensional model and adjusts it based on this study. First of all, the problem of dam delay will be divided into three dimensions according to the tri-dimensional structure, namely China, India, and Pakistan, to make the analysis of the problem more pertinent, and the proposed problem solution more targeted.

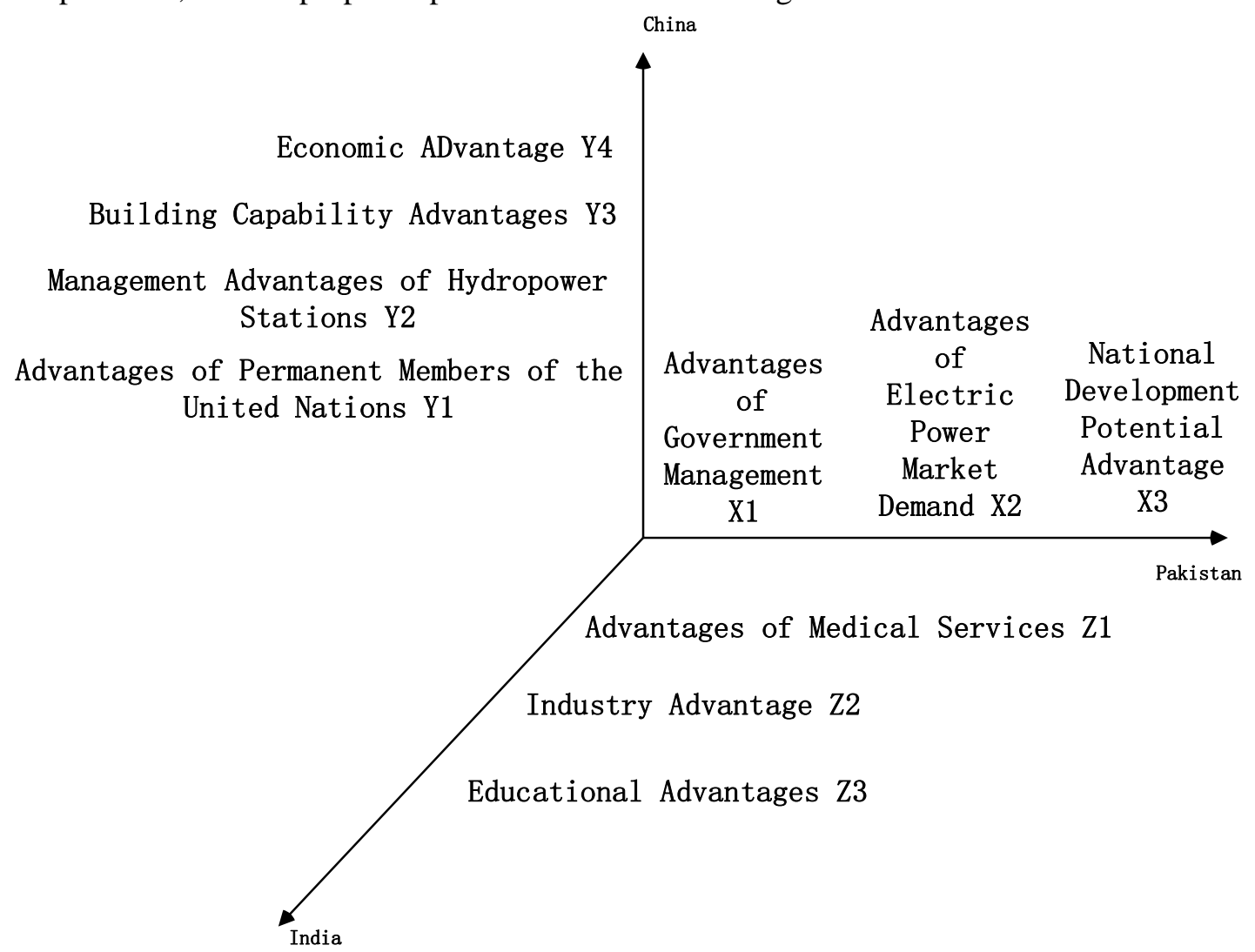

Tri-dimensional Model of Pakistan, China, and India

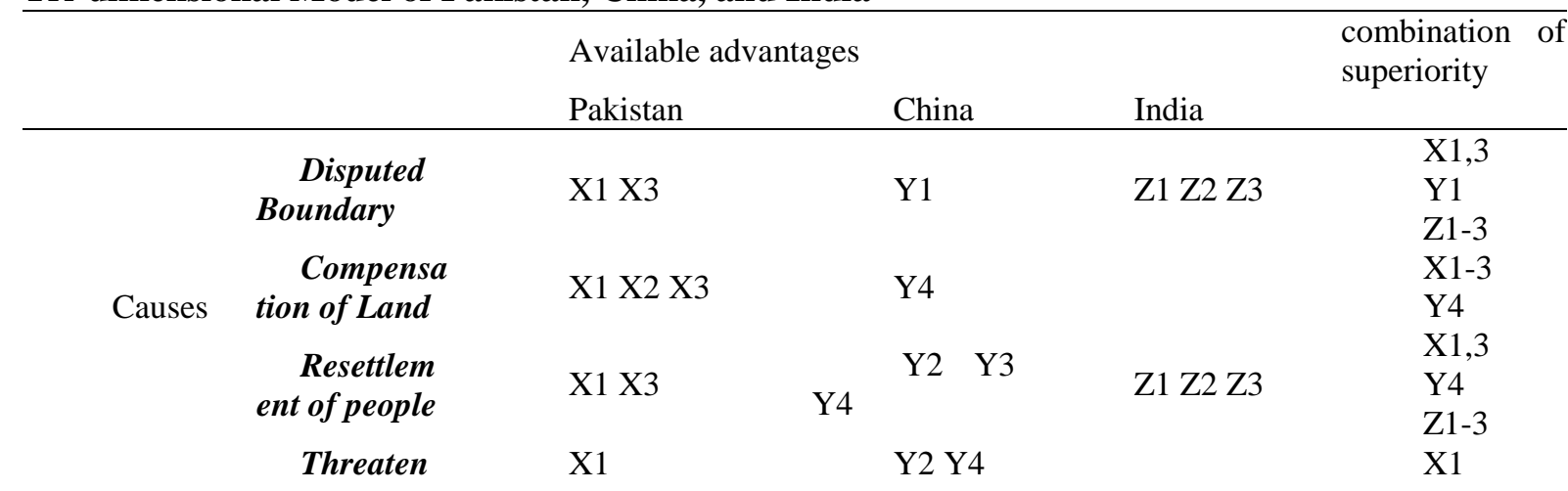


Cultural

Heritage

Ecological

$\mathrm{X} 1$

Y2 Y4

$\mathrm{X} 1$

impact

After analyzing the advantages of the three countries through Hall three-dimensional model, the matrix has been constructed according to the concurrent issue. The direction of solving the problem of dam delay is further analyzed as follows: a combination of will contribute CIEPC. We believe that the solution to the problem of dam delays requires the cooperation of Pakistan, China, and India, so we should consider the advantages of the three countries in dealing with the issue. The different combinations of facts and dimensions among different countries will have peculiar promoting effects on dam problem-solving. In the three national dimensions, Hall's tri-dimensional model is fully used to analyze the problems or advantages of each country. Knowledge dimension, logic dimension, and time dimension have used as follows:

In the knowledge dimension, this study has found the abilities of all three countries to what extent they can work unanimously. For dam construction, the Pakistani government has authority and directness in management. At the same time, the domestic electricity market demand is very high, which stimulates the national development potential. India can provide medical services, educational support, and industrial chain construction for CIPEC. As a permanent member of the United Nations, China can coordinate contradictions in the region from an international perspective. China has ample experience in dam construction, dealing with worse effects made by dam construction and resettlement of mass, and can give economic and building assistance to construct new hometown to promote people's Resettlement. The construction of CIPEC will be more feasible after fully considering the complementary combination of advantages of the three countries.

In the logical dimension, this study has found perspectives of all three countries on the Kashmir dispute and their activities in past. In their policies towards this disputed region, both Pakistan and India claim the whole area while China claims about one part of the region. In this section, we could logically find out which country can play a vital role in solving the issues.

In the time dimension, this study will divide the important event nodes or time nodes after the occurrence of the dam procrastination problem into stages, to make the emergence and development of the dam procrastination problem more thorough understanding.

\section{Problems}

- $\quad$ Azad Kashmir, Gilgit Baltistan (Pakistan Occupied Kashmir) and Jammu \& Kashmir (Indian Occupied Kashmir), Aksai Chin and Trans-Karakoram Tract (China Occupied Kashmir) can never become one state because all the countries are adamant not to move substantively on the issue.

- $\quad$ China, India, and Pakistan are nuclear powers and one spark of fire could become a full-scale nuclear war in the region.

\section{Solutions}

- $\quad$ The name of this entire region should be the United States of Kashmir (USK).

- India, China, and Pakistan should remove all their forces from the United States of Kashmir and international peacekeeping forces should be installed under the umbrella of the United Nation.

- $\quad$ The Line of Control (LOC) and Line of Actual Control (LAC) should be abolished and people should be allowed to travel freely within the entire region of China, India, and Pakistan.

- $\quad$ United Nations should open Asia's largest office in USK to maintain peace.

- $\quad$ USK should be a region of armed neutrality and UNO should be responsible for the safety and security issues of the region.

- $\quad$ USK should be Visa-free territory for Chinese, Indian, and Pakistanis.

- $\quad$ USK should be a Tax-free business and trade zone for China, India, and Pakistan by making Gilgit, Leh, and Srinagar global cities.

- $\quad$ CPEC should be changed into CIPEC (China, India, and Pakistan Economic Corridor).

- $\quad$ China, Pakistan, and India should work and cooperate in all fields like:

- Health

- Education

- $\quad$ Environment 
- Infrastructural development

- Industrial development

- $\quad$ Construction of mega projects like dams

- $\quad$ Good Governance (Democracy should be the political system)

- If Pakistan and Indian do not agree with the above solution then "United Nation Security Council Resolution 47" adopted on April 21, 1948, can be applied to help the governments of India and Pakistan to prepare for a plebiscite to decide the fate of the United States of Kashmir.

Hall's three-dimensional model can solve the dam problem in multi-level and systematically. The scientific research process will lay a foundation for rigorous problem solving, and expect to contribute to the practical solution of the dam delay problems in the future.

\section{FUTURE MODEL. FOR UNITED STATES OF KASHMIR}

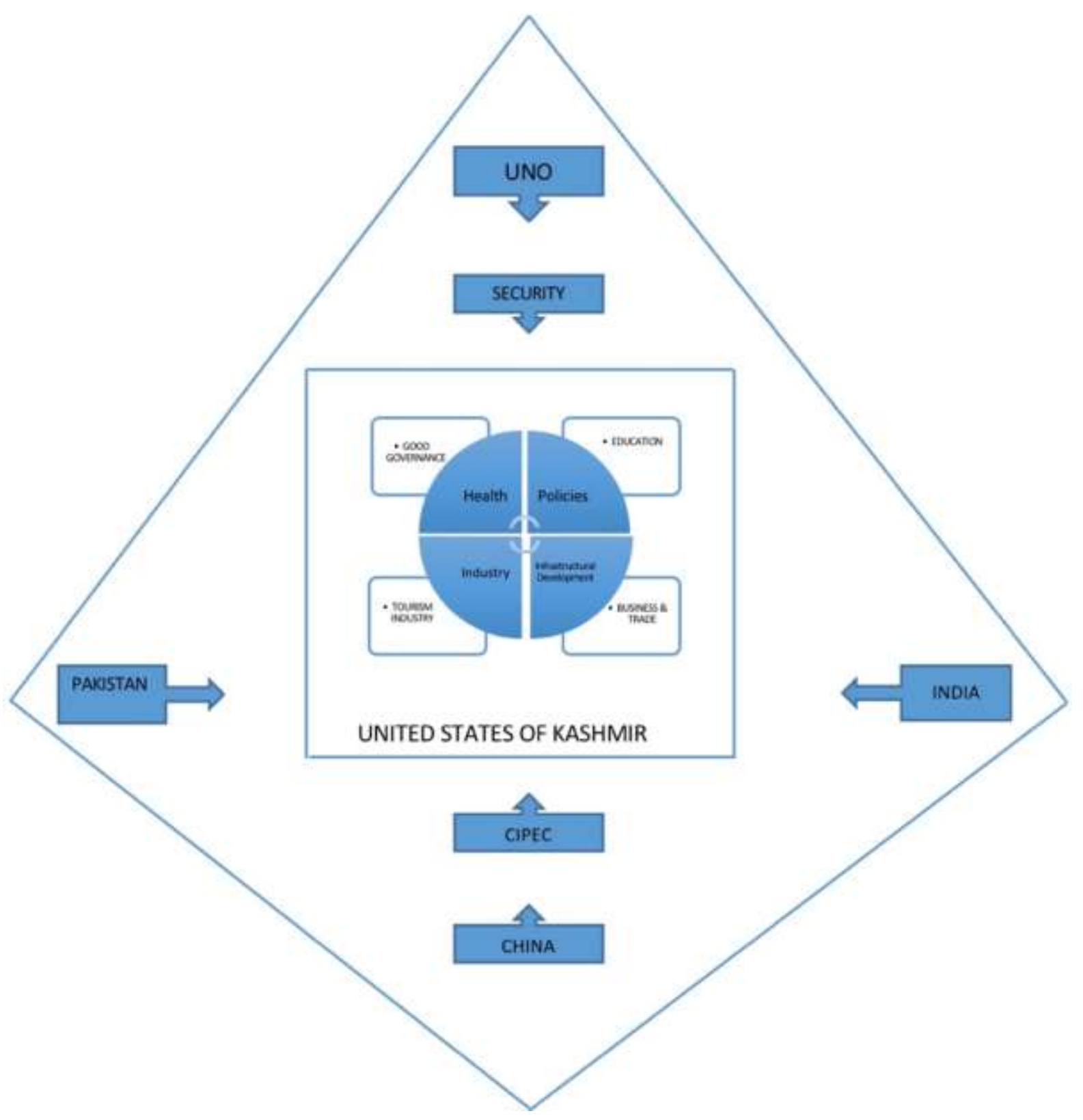




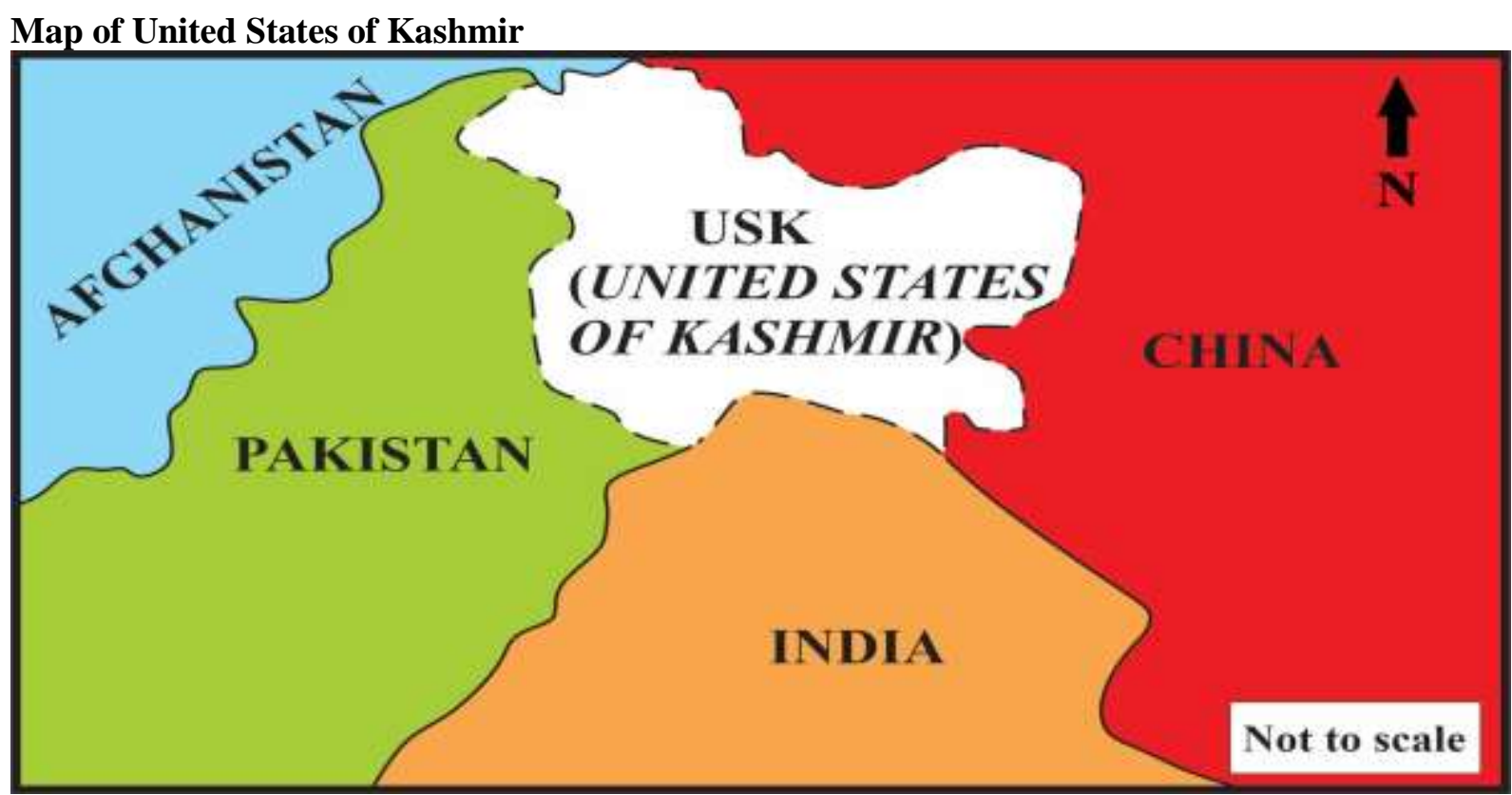

\section{Conclusion}

The peaceful solution of this political Quagmire is unfathomable but this research has presented an unprecedented idea to solve one of the longest-running disputes of contemporary times which has caused immeasurable damages to Pakistan, India, and now China is becoming its part after a long hiatus to add fuel in the fire. This conflict is a hard nut to crack and would not be easy getting the approval from all three nuclear-armed countries for the implementation of the given solution unless international organizations like UNO, UNSC, EU, AU, SCO ASEAN, and OIC coerce all three countries for the sake of the future of the region because this solution will play a pivotal role in changing the fate of entire area where enmity among the countries would become an amicable friendship. The solution will help to utilize the ocean of resources in this region to reap its full benefits because natural resources have inherited the potential to take the countries through the trajectory of growth and development.

$\begin{array}{ll}\text { Abbreviations } & \\ \text { DBD } & \text { Diamar Basha Dam } \\ \text { UNO } & \text { United Nation Organization } \\ \text { UNSC } & \text { United Nation Security Council } \\ \text { EU } & \text { European Union } \\ \text { AU } & \text { African Union } \\ \text { ASEAN } & \text { Association of South East Asian Nations } \\ \text { OIC } & \text { Organization of Islam Countries } \\ \text { SCO } & \text { Shanghai Cooperation Organization }\end{array}$

\section{References}

Ankit, R.; "Kashmir, 1945-66: From Empire to the Cold War", 2014.

Basrur, R. M.; "South Asia's Cold War: Nuclear Weapons and Conflict in Comparative Perspective" (Asian Security Studies). 2008. New York. Routlege.

Bangash, Y.K.; "Three Forgotten Accessions: Gilgit, Hunza, and Nagar", the Journal of Imperial and Commonwealth History. 2010. 38 (1): 117-143,

Calvin, J. B.; "The China-India Border War. 1984.

"Constitution of the Islamic Republic of Pakistan" Part VI, Chapter 1. Finance, Distribution of Revenues between the Federation and the Provinces, p 86. [As modified up to the 28th February 2012].

Haseeb, B.; "Supreme Court asks the public to donate money for the construction of Diamar Basha dam and Mohmand Dam". DAWN, 2018.Available online: https://www.dawn.com/news/ 1417934.

DBD, 2018 a power project launched by WAPDA over Indus River http://www.diamerbhasha.com/ aboutbhasha.html 
Zaffer, B. Diamar Bhasha Dam: Russia wants to take up a project without bidding. The Express Tribune. 12 September 2012. Diamer Bhasha Dam: Russia wants to take up a project without bidding | The Express Tribune. Retrieved 28 August 2013.

Hussain, N.E.; Gilgit Baltistan's Energy Economics. Scribd Inc. 2012. Available online. https://www.scribd.com/document/91799932/Gilgit-Baltistan-s-Energy-Economics.

Ian, H.; Alpamayo to Everest: It's not about the Summit. 2015. Chapter 10, p 6.

Jeffery Gettleman, Hari Kumar, and Sameer Yasir, 2020. Worst Clash in Decades on Disputed IndiaChina Border kills 20 Indian Troops. https://www.nytimes.com/2020/06/16/world/asia/ indian-china-border-clash.html.

Karl, J.; the patolas, their governors and their successors wrote, 1993.

Malik, I.; Kashmir Ethnic Conflict International Dispute. Karachi, 2002. Oxford University Press.

Mallah, S, Two-Nation Theory Exists" Pakistan Times, 2007. Archived from the original on 11 November 2007.

Musarat. J.C, Pakistan - India Conflict with Special Reference to Kashmir, South Asian Studies, A Research Journal of South Asian Studies Vol. 30, No.1, January - June 2015.

Order 2018, Gilgit Baltistan government promulgates GB Order 2018 https://www.geo.tv/latest/196355-gilgit-baltistan-government-promulgates-gb-order-2018

Order 2009, The Gilgit Baltistan (Empowerment and Self-Governance) Order 2009, published by Law Department, GILGIT-BALTISTAN. http://gbla.gov.pk/page/governance-order. https://tribune.com.pk/story/1720017/1-g-b-order-2018-triggers-protest-gilgit/

$\mathrm{P}$, Stobdan. As China intrudes across LAC, India must be alert to a larger strategic shift. The Indian Express, 2020. https://indianexpress.com/article/opinion/columns/the-ladakh-warning-indiachina-border-dispute-6427131/.

Anam, H., Shahbaz, and R.; "Progress report: Pakistan secures credit line for Diamer Bhasha Dam". The Express Tribune, 2013. Progress report: Pakistan secures credit line for Diamer Bhasha Dam | The Express Tribune. Retrieved 28 August 2013.

Rai, M.; Hindu Rulers, Muslim Subjects: Islam, Rights, and the History of Kashmir, 2004. Princeton University Press. pp. 27, 133.

Sahni, S. P.; "The Ceasefire Line and Line of Control in Jammu and Kashmir: Evolution of a border", in K. Warikoo, Himalayan Frontiers of India: Historical, Geo-Political and Strategic Perspectives, Routledge, pp. 67-77. 2009.

Senge, S.; China's Interest in Shaksgam Valley. Institute for Gilgit Baltistan Studies. October 10, 2013, http://www.sharnoffsglobalviews.com/china-shaksgam-valley-191/.

Sen, T.; Buddhism, Diplomacy, and Trade: The Realignment of India-China Relations, 600-1400". 2015.

Shahid, J. B.; Historical Dictionary of Pakistan”. 2015, Rowman \& Littlefield Publishers p 228.

Weightman, B. A.; Dragons and Tigers: A Geography of South, East, and Southeast Asia. 2005 (2nd Ed.). John Wiley \& Sons. P. 193.

World Bank to finance USD 14 billion in Pakistani Dam". Kuwait News Agency. 21 August 2013. Retrieved 27 August 2013.

Work on Diamar Basha Dam to start from May 2019. Available online: https://tribune.com.pk/story/ 1856360/1-work-diamer-bhasha-dam-start-may-2019/ 